\title{
Effects of deforestation on water erosion rates in the Amazon region
}

Guilherme Henrique Expedito Lense ${ }^{1} \oplus$, Junior Cesar Avanzi, Taya Cristo Parreiras ${ }^{1}\left[\right.$, Ronaldo Luiz Mincato ${ }^{1} \mathbb{0}$

\footnotetext{
1 Universidade Federal de Alfenas, Alfenas, MG, Brasil. E-mail: guilhermeelense@gmail.com; tayacristo1@gmail.com; ronaldo.mincato@unifal-mg.edu.br

2 Universidade Federal de Lavras, Lavras, MG, Brasil. E-mail: junior.avanzi@ufla.br
}

ABSTRACT: Deforestation in the Amazon Rainforest is a recurring theme on the national and international environmental agenda. However, little attention has been given to its influence on water erosion and soil degradation. This study aimed to model the effect of deforestation on the spatial and temporal variation of water erosion in a watershed of the Amazon region. Therefore, we hypothesize that the expansion of deforestation, and the consequent changes in land use and cover, contributed to increasing soil losses due to water erosion. The Xingu River watershed was selected as a study area once it is one of the most affected regions by deforestation in the Brazilian Amazon. The estimate of water erosion was performed in the years 1988, 1998, 2008, and 2018 using the Potential Erosion Method (EPM). The application of the model was carried out in a Geographic Information System environment. Between 1988 and 2018, the deforestation in the selected basin increased by $12 \%\left(52,258 \mathrm{~km}^{2}\right)$. In the same period, water erosion increased by $312 \%$, corresponding to about 180 million tons of soil lost per year. The result of the study can help in planning erosion control in the Amazon region.

Key words: cover change; land use; soil conservation; soil loss

\section{Efeito do desmatamento sobre as taxas de erosão hídrica na região amazônica}

RESUMO: O desmatamento da Floresta Amazônica é tema recorrente na agenda ambiental nacional e internacional, porém pouca atenção tem sido dada a sua influência na erosão hídrica e na degradação dos solos. Este estudo objetivou modelar o efeito do desmatamento sobre a variação espacial e temporal da erosão hídrica na região Amazônica. Nossa hipótese é que a expansão do desmatamento e as consequentes mudanças no uso e cobertura da terra, contribuíram para aumentar as perdas de solo pela erosão hídrica. A Bacia Hidrográfica do Rio Xingu foi selecionada como área de estudo por ser uma das regiões mais afetadas pelo desmatamento na Amazônia Brasileira. A estimativa da erosão hídrica foi realizada nos anos de 1988, 1998, 2008 e 2018 utilizando o Método de Erosão Potencial (EPM). A aplicação do modelo foi realizada em ambiente de Sistema de Informação Geográfica. Entre 1988-2018, ocorreu um aumento de 12\% (52.258 km²) no desmatamento da floresta amazônica da bacia. No mesmo período houve um crescimento na erosão hídrica em 312\% correspondente a cerca de 180 milhões de toneladas de solo perdido por ano. 0 resultado do estudo pode auxiliar no planejamento de controle da erosão na região amazônica.

Palavras-chave: mudanças no uso; uso da terra; conservação do solo; perda de solo 


\section{Introduction}

Soils are an essential component of the terrestrial system that produces food, biomass, and raw materials, provides a habitat for flora and fauna, sequester carbon, and manages water, minerals, and biological cycles (Cerdà et al., 2018). In tropical regions, this resource is often degraded due to water erosion, leading to a decline in fertility and its ability to sustain life (Martínez-Mena et al., 2020).

In the Brazilian Amazon region, deforestation intensifies water erosion, mainly during the conversion of deforested areas to agricultural and pasture areas. Although deforestation in the Amazon rainforest is a relevant and recurring topic on the national and international environmental agenda (Tacconi et al., 2019), little is discussed about the influence of this deforestation on erosion rates and soil degradation. Thus, the assessment of the dynamics of the erosion process due to deforestation and the consequent changes in land use and occupation in the region is essential to highlight the importance of soil conservation and assist in proposing effective strategies to reduce erosion (Efthimiou et al., 2017).

Due to the dimensions of watersheds in the Amazon region and the low availability of information, modeling is an alternative to estimate water erosion and provide a diagnosis of soil losses (Batista et al., 2017). The model application is simple, of low cost, and it can be combined with Geographic Information Systems (GIS) to estimate erosion rates in both spatial and temporal scale. Moreover, it represents the possibility of a remote investigation of the erosion process (Luetzenburg et al., 2020).

In Europe, modeling of large areas often helps in the proposal and adoption of environmental and agricultural policies to decrease the negative impacts of erosion. The European Union (EU) itself has implemented soil protection and conservation in its common agricultural policy to prevent soil degradation (Panagos et al., 2015; Alewell et al., 2019). In Brazil, although modeling studies are not widely used by the government agencies, the estimate of water erosion, as well as the understanding of its temporal dynamics, can be used as a tool in planning the sustainable management of watersheds. Besides, there are no studies that estimate water erosion in large hydrographic basins in the Brazilian Amazon.

In this context, we aimed to model the effect of deforestation on the spatial and temporal variation of water erosion in a sub-basin of the Amazon region. As a hypothesis, it is believed that the expansion of deforestation and consequent changes in land use and cover, contributed significantly to increase soil losses due to water erosion in the region.

\section{Materials and Methods}

\section{Study area description}

The Xingu River watershed was selected for the study once it is one of the areas most affected by deforestation in the Amazon region (Villas-Bôas, 2012). The watershed has a drainage area of $508,348 \mathrm{~km}^{2}$, located between the states of
Pará and Mato Grosso, Brazil, at coordinates 55o $36^{\prime} 14^{\prime \prime}$ to

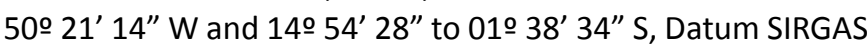
2000.

The Xingu River has an average annual flow of about 8,000 $\mathrm{m}^{3} \mathrm{~s}^{-1}$, which makes it the fifth-largest tributary of the Amazon River. The source of the Xingu River is located in the State of Mato Grosso, and it flows north for about 2,000 km before reaching the Amazon River, in the State of Pará (Dias et al., 2015).

The watershed covers an ecological transition area with a wide variety of vegetation, resulting from the environmental dynamics generated by the meeting of the Cerrado and Amazon biomes (Villas-Bôas, 2012). The Köppen climate classification for the region is represented in Figure 1 (Alvares et al., 2013).

The estimate of water erosion due to deforestation and land use and cover changes in the watershed was performed in the years of 1988, 1998, 2008, and 2018, because the year of 1988 the Amazon deforestation started to be monitored with satellite images, adopting a 10 year timescale after the start of monitoring.
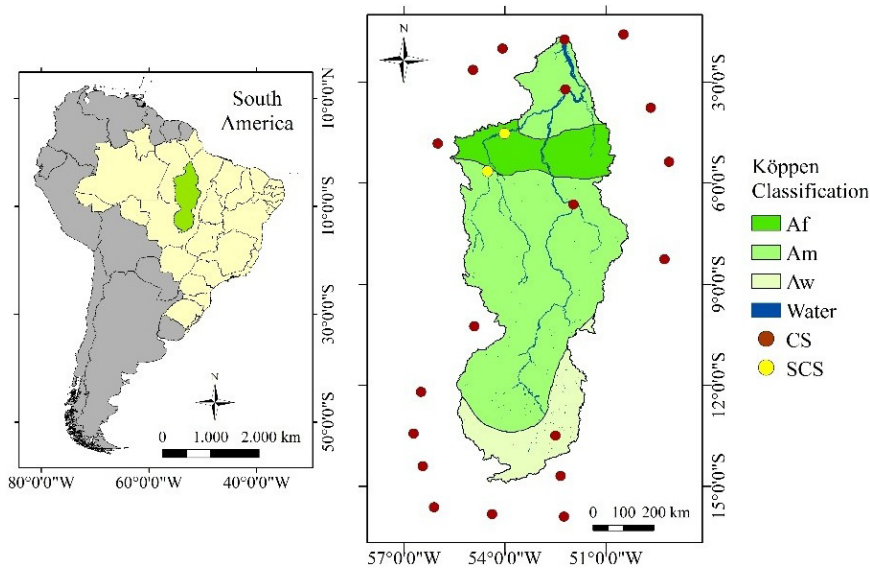

Figure 1. Location and Köppen climate classification of the Xingu River watershed, Brazil. Notes: tropical climate without dry season (Af), tropical monsoon climate (Am), tropical climate with dry winter (Aw), climatological stations (CS), sediment collection stations (SCS). Köppen's classification adapted from Alvares et al. (2013).

\section{Water erosion modeling}

Amongst several models available for soil loss estimate, the Erosion Potential Method (EPM) was selected (Gavrilovic, 1962) because it is a model widely applied worldwide (Efthimiou et al., 2017). The parameter obtaining is not complicated, as well as its application, advantages that make it ideal for a region with low information availability. Also, the model has recently been adapted to Brazilian edaphoclimatic conditions, presenting accurate and reliable results (Sakuno et al., 2020). EPM estimates soil losses according to Equation 1.

$\mathrm{W}_{\mathrm{yr}}=\left(\sqrt{\frac{\mathrm{t}_{0}}{10}}+0.1\right) \cdot \mathrm{H}_{\mathrm{yr}} \cdot \pi \cdot \sqrt{\left[\mathrm{Y} \cdot \mathrm{X}_{\mathrm{a}} \cdot\left(\varphi+\sqrt{\mathrm{I}_{\mathrm{sr}}}\right)\right]^{3}} \cdot \mathrm{Bd} \cdot \mathrm{F}$ 
where: $\mathrm{W}_{\mathrm{yr}}=$ total loss of soil, in $\mathrm{Mg} \mathrm{ha}^{-1}$ year $^{-1} ; \mathrm{t}_{0}=$ average air temperature, in ${ }^{\circ} \mathrm{C}$ year ${ }^{-1} ; \mathrm{H}_{\mathrm{yr}}=$ annual rainfall, in $\mathrm{mm}$ year ${ }^{-1}$; $Y=$ soil resistance to water erosion, dimensionless; $X_{a}=$ use and management coefficient, dimensionless ; $\phi=$ coefficient of the degree of erosive features, dimensionless; $I_{s r}=$ average slope of the area, in \%, Bd = average soil bulk density, in $\mathrm{kg}$ $\mathrm{dm}^{-3}$; and $\mathrm{F}=$ area, in ha.

The climatic factors $\left(\mathrm{H}_{\mathrm{yr}}\right.$ and $\left.\mathrm{t}_{0}\right)$ were obtained based on the network of meteorological stations of the National Institute of Meteorology, distributed inside and near the watershed (Figure 1). The climatic data were interpolated by the ordinary kriging method, with adjustment of the spherical model, using the Geostatistical Wizard tool of the ArcGIS 10.3 software (ESRI, 2015). The spatial distribution maps of $H_{y r}$ and $t_{0}$ are illustrated in Figures 2 and 3, respectively.

Amongst the studied years, 2008 had the highest average accumulated precipitation ( $2077 \mathrm{~mm}^{-1} \mathrm{year}^{-1}$ ), followed by 2018 (2015 mm year-1), 1988 (2012 mm year-1), and 1998 (1672 mm year $\left.^{-1}\right)$. The average air temperature in the watershed was $25.8,26.6,26.1$, and $26.5^{\circ} \mathrm{C}_{\text {year }}{ }^{-1}$ in $1988,1998,2008$, and 2018, respectively.

The coefficient of land use and management $\left(X_{a}\right)$ represents the soil protection against the impact of raindrops and runoff due to the vegetation cover. The values ranged from 0.05 , in areas with dense vegetation, to 1.00 , for areas with bare soil (Gavrilovic, 1962). This parameter is particularly important for our work, as it reflects the density of the vegetation cover and thus the deforestation rates at the studied watershed.

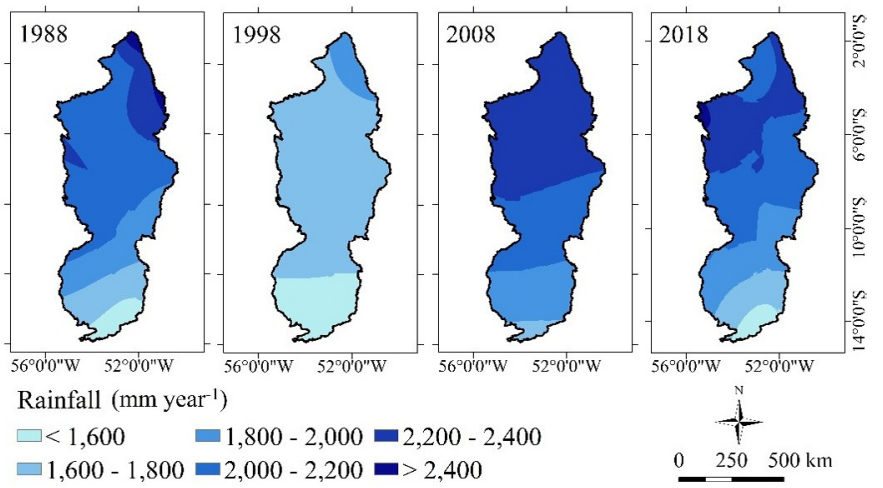

Figure 2. Annual rainfall $\left(\mathrm{H}_{\mathrm{yr}}\right)$ in the Xingu River watershed, Brazil, in the years of 1988, 1998, 2008, 2018.
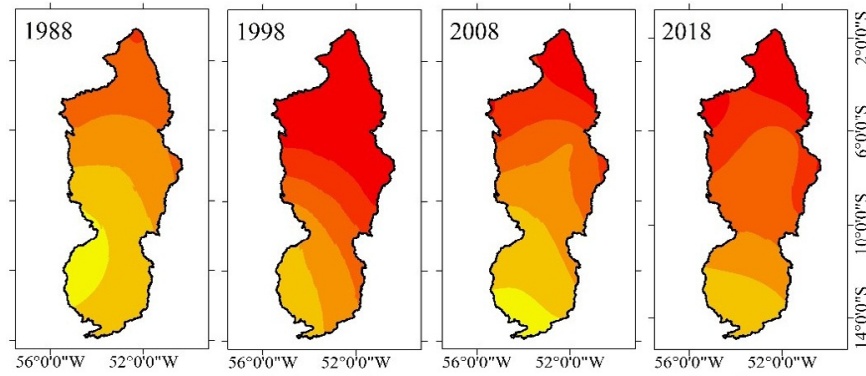

Average air temperature $\left({ }^{\circ} \mathrm{C}_{\text {year }}{ }^{-1}\right)$ $\square<25.0 \square 25.5-26.0 \square 26.5-27.0$ $\square 25.0$ - $25.5 \square 26.0-26.5 \square>27.0$

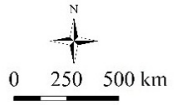

Figure 3. Average air temperature $\left(t_{0}\right)$ in the Xingu River watershed, Brazil, in the years of 1988, 1998, 2008, 2018.

The parameter $\mathrm{X}_{\mathrm{a}}$ was determined using tabulated values that were initially proposed by Gavrilovic (1962), and then adapted to Brazilian edaphoclimatic conditions by Sakuno et al. (2020). For the classification of parameter $X_{a}$ (Table 1 ), maps of land use and occupation were used in the years of 1988, 1998, 2008, and 2018 (MapBiomas Project, 2018) (Figure 4).

Table 1 shows the percentages of the area occupied by each class of land use.

The $\phi$ factor indicates the erosion feature that predominates in each sit. For each type, the parameter receives a tabulated value, ranging from 0.10 , for areas without any erosion features, to 1.00 , for those with severe signs of erosion. Due

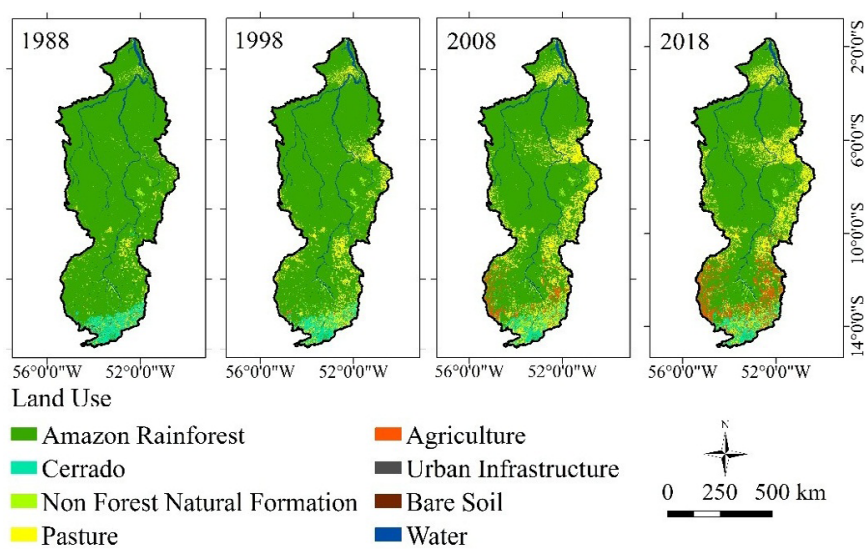

Figure 4. Land use map of the Xingu River watershed, Brazil, in the years of 1988, 1998, 2008, 2018. Adapted from the MapBiomas Project (2018).

Table 1. Classes of land use, and values adopted for the land use and management $\left(X_{a}\right)$ coefficient, and the visible erosion features $(\phi)$ coefficient at the Xingu River watershed, Brazil.

\begin{tabular}{|c|c|c|c|c|c|c|}
\hline \multirow{2}{*}{ Land use } & 1988 & 1998 & 2008 & 2018 & $X_{a}^{* *}$ & $\phi^{* * *}$ \\
\hline & \multicolumn{4}{|c|}{ Area (\%) } & \multicolumn{2}{|c|}{ (dimen.) } \\
\hline Amazon Rainforest & 89.77 & 85.25 & 77.40 & 74.97 & 0.05 & 0.1 \\
\hline Cerrado & 4.46 & 3.78 & 3.19 & 3.13 & 0.30 & 0.2 \\
\hline Non Forest Natural Formation & 1.12 & 1.20 & 1.23 & 1.55 & 0.40 & 0.2 \\
\hline Pasture & 3.18 & 8.28 & 14.6 & 13.57 & 0.50 & 0.5 \\
\hline Agriculture & 0.18 & 0.32 & 2.43 & 5.60 & 0.70 & 0.6 \\
\hline Bare Soil & 0.18 & 0.06 & 0.04 & 0.02 & 0.90 & 0.7 \\
\hline Urban Infrastructure* & 0.01 & 0.01 & 0.01 & 0.06 & - & - \\
\hline Water* & 1.10 & 1.10 & 1.10 & 1.10 & - & - \\
\hline
\end{tabular}

* Areas not considered in the calculation of estimated soil loss. ${ }^{* *}$ Values classified according to Sakuno et al. (2020). *** Values adapted from Lense et al. (2019) and Sakuno et al. (2020). Notes: dimen.= dimensionless. 
to the wide extension of the watershed, which makes it hard to identify these features in situ, the $\phi$ factor was classified according to the land use, using as reference values reported in the specialized literature (Table 1 ).

The $Y$ parameter varies from 0.20 to 2.00 and represents the resistance of each type of soil to water erosion, on what those with higher $Y$ values are less resistant. Therefore, it was determined according to Sakuno et al. (2020), and classified for each soil type of the watershed: Gleysols (0.5), Latosols (0.8), Nitosols (0.8), Argisols (0.9), Plinthosols (0.9), Cambisols (1.0), Litholic Neosols (1.4), and Quartzarenic Neosols (1.5). The soil classes were defined using the digital soil map of the area (IBGE \& Embrapa, 2001), and they are mostly: Argisols (52.3\%), Latosols (27.5\%), and Litholic Neosols (8.2\%) (Figure $5 A)$.

The $I_{s r}$ factor represents the influence of the relief on the erosive process. The slope map of the Xingu River watershed, with a spatial resolution of 30 meters (Figure $5 \mathrm{C}$ ), was elaborated using the ArcMap 10.3 Slope tool (ESRI, 2015), based on the watershed digital elevation model (Figure 5B), obtained in the digital platform Brazil in Relief of the Empresa Brasileira de Pesquisa Agropecuária. The basin has predominantly smooth wavy relief, with an average slope of $5.3 \%$.

In the basin, the value of $\mathrm{Bd}$ was determined using reference values reported in the specialized literature: Latosols $-1.18 \mathrm{~kg}$ $\mathrm{dm}^{-3}$, Quartzarenic Neosols $-1.23 \mathrm{~kg} \mathrm{dm}^{-3}$, Cambisols $-1.30 \mathrm{~kg}$ $\mathrm{dm}^{-3}$, Argisols $-1.31 \mathrm{~kg} \mathrm{dm}^{-3}$, Nitosols $-1.32 \mathrm{~kg} \mathrm{dm}^{-3}$, Plinthosols - $1.40 \mathrm{~kg} \mathrm{dm}^{-3}$, Litholic Neosols - $1.45 \mathrm{~kg} \mathrm{dm}^{-3}$, and Gleysols $1.47 \mathrm{~kg} \mathrm{dm}^{-3}$ (Baena \& Dutra, 1982; Wadt, 2004; Medeiros et al., 2013; Oliveira et al., 2015). Bd is a parameter incorporated in the original EPM formula, to convert volume to mass $\left(\mathrm{m}^{3}\right.$ year $^{-1}$ to $\mathrm{Mg} \mathrm{year}^{-1}$ ). The calculations referring to EPM and the spatial distribution of the results were made in GIS using the Raster Calculator tool from ArcGIS 10.3 (ESRI, 2015).

\section{Validation}

At Xingu River watershed, the vast majority of hydrosedimentological sample stations are inoperative or

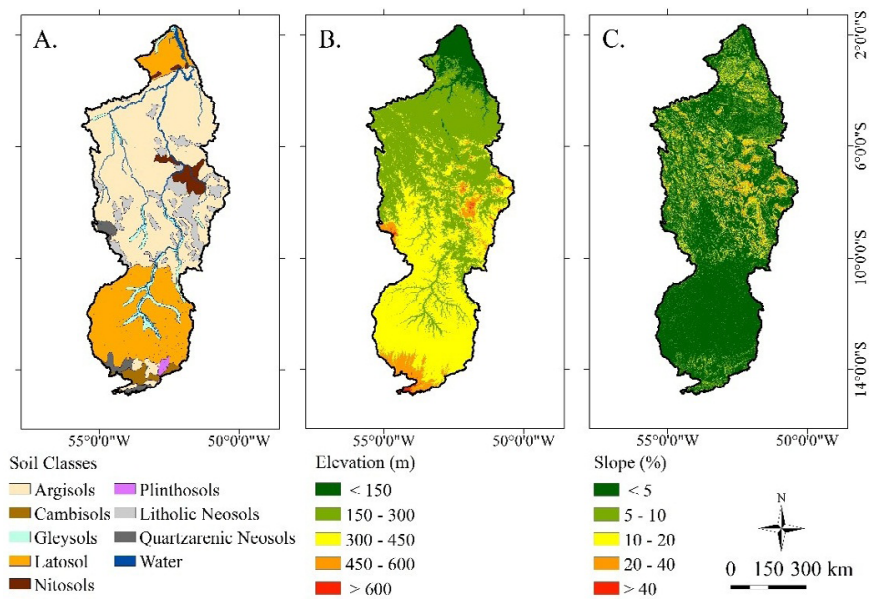

Figure 5. Digital soil map (A), digital elevation (B), and slope (C) model of the Xingu River Basin, Brazil. Digital soil map adapted from IBGE \& Embrapa (2001). with unavailable data. Therefore, the results of this work were validated according to the methodology proposed by Batista et al. (2017). For this purpose, two sediment sample stations, regulated by the National Water Agency (ANA) (Figure 1). The stations are inserted in a drainage confluence area of 122,000 $\mathrm{km}^{2}$, as informed by ANA.

Data were collected on total sediments transported with the discharge of water and flow, monitored between the years of 1984 and 2019. With this data, a discharge curve was constructed (Figure 6). Then, the annual sediment transported (Observed SD) in the watershed, in each season, was calculated, taking into account the flow versus sediment curve and the set of daily runoff data in the years 1988, 1998, 2008, and 2018, also obtained in ANA.

To compare the Observed SD values with the results provided by the EPM, it is necessary to integrate the model with the sediment delivery rate (SDR). The SDR allows us to estimate the fraction of eroded soil of a given area that reaches the water bodies. The SDR was determined using Equation 2, as proposed by Vanoni (1975).

$$
\mathrm{SDR}=0.472 \cdot \mathrm{A}^{-0.125}
$$

where: SDR is the sediment delivery rate, in $\%$, and $A$ is the catchment area in $\mathrm{km}^{2}$.

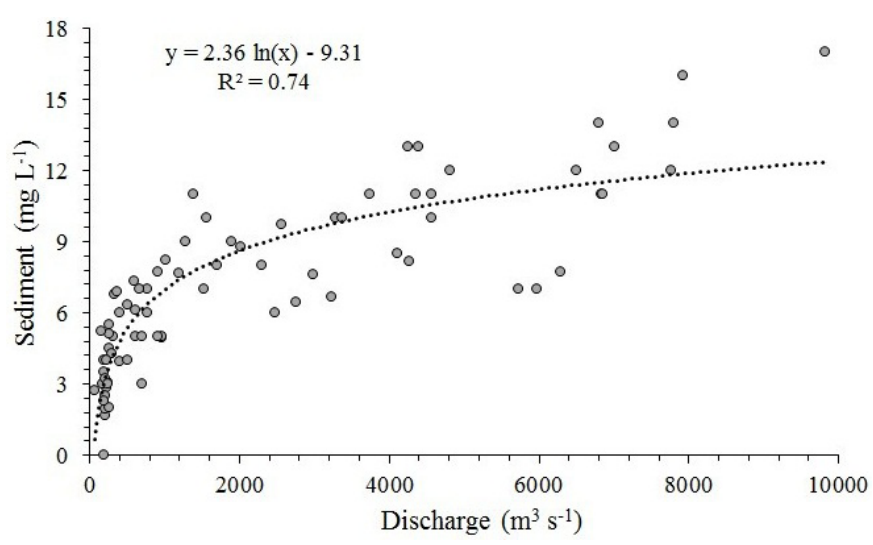

Figure 6. Water discharge curve (sediment transported versus water discharge), of the Xingu River watershed, Brazil.

\section{Results and Discussion}

\section{Spatial and temporal distribution of soil losses at Xingu River watershed}

Between 1988 and 2018, 12\% of the Xingu River watershed Amazon Forest area was deforested, which is equivalent to $52,258 \mathrm{~km}^{2}$. The lowest rate of deforestation was observed in the 1998-2008 period (Table 1). The deforestation reduction in the region, in the current years, is due to the combination of economic factors, such as fluctuations in commodities prices, and government command and control actions, with emphasis on the Deforestation Prevention and Control Plan in the Legal Amazon (Villas-Bôas, 2012; Reydon et al., 2019). However, despite this reduction observed, the Xingu River watershed still has high rates of deforestation: only in 2019, 
168,111 ha were deforested. Deforestation in the region remains alarming and in the first four months of 2020, 35,673 ha of Amazon Forest have been deforested (SiradX, 2019, 2020a,b).

Analyzing the deforestation rates, we noticed an increase in pastures and agricultural fields in areas previously occupied by the Amazon rainforest and the Cerrado biome, respectively (Figure 4). The results agree with Dias et al. (2016), whose analysis of the expansion of agriculture in Brazil found a significant increase in agricultural land and pastures in the states of Mato Grosso and Pará between 1985-2012.

As expected, the elevation of deforestation and the landuse changes were followed by an increase in soil losses (Table 2 ). Between 1988-2018, the estimated erosion rates increased by $312 \%$, corresponding to about 180 million tons of soil lost per year. Due to this rise, the highest average rate was estimated in 2018 (4.7 $\mathrm{Mg} \mathrm{ha}^{-1}$ year $^{-1}$ ).

In the entire period of the study, regardless of the year, there was the predominance of low erosion rates $(<2.5 \mathrm{Mg}$ ha year $^{-1}$ ) due to the high presence of the native forest (Amazon Rainforest) in the watershed (Table 3). However, there was an increase of $531 \%$ of areas presenting high erosion rates (> $10.0 \mathrm{Mg}$ ha year $\left.{ }^{-1}\right): 2.6 \%$ in $1998,5.7 \%$ in $1998,14.1 \%$ in 2008 , and $16.7 \%$ in 2018 . Figure 7 shows the maps with the spatial distribution of soil losses in each season studied.

In both years, average soil loss rates above $10.0 \mathrm{Mg}$ ha year $^{-1}$ occurred in the areas of exposed soil, agriculture, and pastures (Table 3). Land use beyond agricultural potential, fragile soils with inadequate management, and the absence of conservation practices can be the causes of the intensification of erosion in such land uses (Medeiros et al., 2016).

Table 2. Annual soil loss estimated during 1988, 1998, 2008 and 2018, in the Xingu River watershed, Brazil.

\begin{tabular}{ccc}
\hline \multirow{2}{*}{ Year } & \multicolumn{2}{c}{ Soil loss } \\
\cline { 2 - 3 } & $\left(\right.$ Mg ha $^{-1}$ year $\left.^{-1}\right)$ & $\left(\right.$ Mg year $\left.^{-1}\right)$ \\
\hline 1988 & 1.13 & $57,892,886$ \\
1998 & 1.70 & $86,318,438$ \\
2008 & 4.20 & $214,366,256$ \\
2018 & 4.70 & $238,658,936$ \\
\hline
\end{tabular}
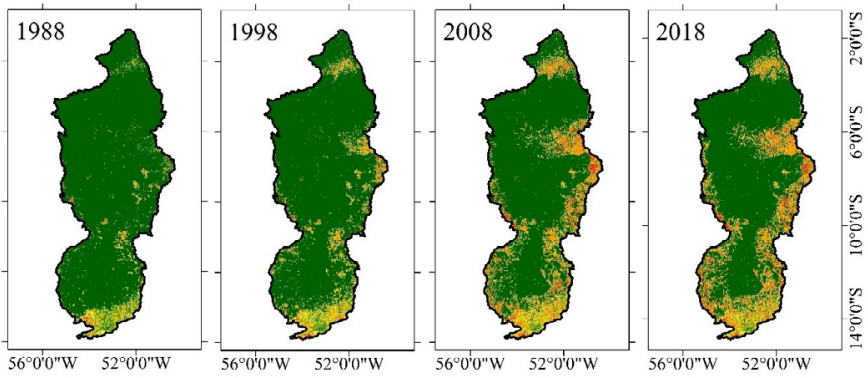

Soil Losses (Mg ha year-1)

$\square<2.5 \square 5.0-10.0 \square>30.0$

$\square 2.5-5.0 \square 10.0-30.0$

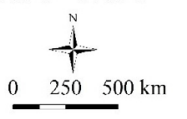

Figure 7. Spatial distribution of soil losses in the Xingu River watershed, Brazil, in the years 1988, 1998, 2008, 2018.
Table 3. Values of water erosion in each land-use class in the years of 1988, 1998, 2008, and 2018 at the Xingu River watershed, Brazil.

\begin{tabular}{ccccc}
\hline \multirow{2}{*}{ Land use } & $\mathbf{1 9 8 8}$ & $\mathbf{1 9 9 8}$ & $\mathbf{2 0 0 8}$ & $\mathbf{2 0 1 8}$ \\
\cline { 2 - 5 } & \multicolumn{5}{c}{$\mathbf{( M g ~ h a}^{-1}$ year $\left.^{-1}\right)$} \\
\hline Amazon Rainforest & 0.5 & 0.6 & 1.4 & 1.5 \\
Cerrado & 6.2 & 6.4 & 8.5 & 8.6 \\
\hline Non Forest Natural Formation & 6.0 & 5.9 & 8.0 & 8.0 \\
Pasture & 8.4 & 9.5 & 14.8 & 15.0 \\
Agriculture & 15.4 & 16.3 & 19.3 & 19.3 \\
Bare Soil & 20.1 & 17.0 & 19.7 & 17.5 \\
\hline
\end{tabular}

\section{Sediment delivery ratio (SDR)}

At the Xingu River watershed, the SDR estimated was 0.091 , indicating that $9.1 \%$ of the eroded sediments reach water bodies, contributing to the silting and depreciation of water quality. The estimated sediment transport (Estimated SD) ranged from 0.046 to $0.108 \mathrm{Mg} \mathrm{ha}^{-1}$ year $^{-1}$ (Table 4).

As for Observed SD, in 1998, the value was smaller than in the other seasons $\left(0.041 \mathrm{Mg} \mathrm{ha}^{-1}\right.$ year $\left.^{-1}\right)$ due to the lower precipitation rate this year (Figure 2). How it was calculated based on the water flow, its results were influenced by the precipitation rates at the watershed.

When compared the values of Observed SD and Estimated SD for the years of 2008 and 2018, EPM overestimated the sediment delivery by 0.022 and $0.033 \mathrm{Mg} \mathrm{ha}^{-1}$ year $^{-1}$, respectively, which corresponds to absolute errors of 33.9 and $44.6 \%$. However, the errors were lower in the years of 1988 and 1998, which may be considered acceptable (Table 4) when taking into account the large extension of the watershed.

The wide variance of the vegetation cover index $\left(X_{a}\right)$ during the period of the study can explain the range of the errors. Due to the high sensitivity of variation, this parameter decisively interferes in the results provided by the EPM (Dragičević et al., 2017). Also, regardless of the period, Xingu River watershed presented a high percentage of native vegetation, which minimizes the rate of sediment delivery for two reasons: i) directly, due to the low rates of water erosion observed in this type of land-use, and ii) indirectly, because the vegetation around the watercourses also acts as a physical barrier, preventing part of the eroded sediments from reaching river beds. Therefore, this increases the SDR estimation error since the model does not simulate this indirect effect.

According to Bagarello et al. (2012), when used for more practical purposes, estimates of soil loss carried out on a large spatial scale are considered accurate if the forecast

Table 4. Sediment transport estimated and observed during 1988, 1998, 2008, and 2018 in the Xingu River watershed, Brazil.

\begin{tabular}{cccc}
\hline \multirow{2}{*}{ Year } & Estimated SD & Observed SD & \multirow{2}{*}{$\begin{array}{c}\text { Error } \\
\text { (\%) }\end{array}$} \\
\cline { 2 - 3 } & \multicolumn{2}{c}{$\left(\mathbf{M g ~ h a}^{-1}\right.$ year $\left.^{-1}\right)$} & 20.7 \\
1988 & 0.046 & 0.058 & 21.8 \\
1998 & 0.050 & 0.041 & 33.9 \\
2008 & 0.087 & 0.065 & 44.6 \\
\hline 2018 & 0.108 & 0.075 & \\
\hline
\end{tabular}

Notes: $\mathrm{SD}=$ sediment delivery. 
errors do not exceed the erosion observed by a factor of two or three. Therefore, the results of this work are reliable and might assist in the decision making and management of the Xingu River watershed. Moreover, the relative lack of direct measurements of soil losses and sediment transport in the Amazon region highlights the importance of erosion forecasting models to obtain a diagnosis of the process, assisting in its understanding.

\section{Measures to reduce soil erosion}

In the current years, the main action to be adopted in the watershed to reduce soil loss rates is the reduction of deforestation, which will only be achieved with the engagement and encouragement of the Brazilian Government. The public power should aim for the correct application, and oversight, of well-directed and effective public policies (Jung \& Polasky, 2018; Reydon et al., 2019). According to Stabile et al. (2020), innovations to increase the productivity of agricultural lands in the region, which reduce the need for the expansion of new agricultural frontiers, along with the payment for environmental services provided by the vegetation cover are also actions that can effectively contribute to the reduction of deforestation rates.

Due to the high erosive rates in the areas of exposed soil, agricultural land, and pastures (Table 3), it is necessary to disseminate agronomic practices aimed at preservation in such areas. Therefore, actions like maintaining the vegetation cover, the no-till, and green planting, help to increase soil protection against the rainfalls and the runoff (Martínez-Mena et al., 2020; Wen \& Zhen, 2020). Moreover, land use and occupation planning should also be carried out at Xingu River watershed according to its agricultural suitability, especially in more fragile soils that have a high susceptibility to erosion (Litholic Neosols, Quartzarenic Neosols, and Cambisols).

According to Dias et al. (2015), the average total discharge on the agricultural land of the watershed is about $100 \%$ higher than those with natural vegetation, which is dangerous since the runoff, associated with erosion, can lead to the transportation of fertilizers residues, causing the contamination of water bodies. Therefore, conservationist practices to minimize the runoff can also contribute to improve the water quality and to reduce the risk of eutrophication. Also, the Belo Monte Hydroelectric Plant, located at the Xingu River watershed, can be beneficiated by the reduction of the erosive processes, since it will lead to lower rates of silting up, increasing its useful life.

It is worth mentioning that deforestation in the Xingu River watershed has a direct effect on the emission of greenhouse gases, and indirect due to the intensification of erosion since gaseous emissions from the soil occur during the erosion stages and in the deposition of sediments. Therefore, reducing deforestation, and consequently, water erosion, minimizes the greenhouse effect and global warming (Lal, 2019).

Finally, this work aimed to introduce the Soil Conservation theme into the agenda of global discussions about the environment. The deforestation of the Amazon region, along with several regional and global negative effects, also leads to soil degradation. However, few references are made until nowadays, and this is scenario can threaten the Amazon rainforest sustainability. The soil is a finite natural resource, which makes the water erosion one of the biggest threats for the environment in the human history, thus, if not properly managed, it can be depleted in a human time scale (Medeiros et al., 2016).

\section{Conclusion}

Deforestation and changes in land use between 19882018 in the Xingu River watershed, in the Amazon region, intensified the erosion process causing high soil losses. Between 1988-2018, there was an annual increase in erosion rates corresponding to million tons of soil lost per year.

Therefore, the result of this study is a useful tool for erosion control planning in the Amazon region, and for the identification of areas with high rates of soil loss in the Xingu River watershed, that are a priority for the adoption of measures to mitigate erosion.

\section{Acknowledgments}

The authors thank the Fundação de Amparo à Pesquisa do Estado de Minas Gerais (FAPEMIG) for the scholarship offered to the first author. This study was financed in part by the Coordenação de Aperfeiçoamento de Pessoal de Nível Superior - Brasil (CAPES) - Finance Code 001.

\section{Literature Cited}

Alewell, C.; Borrelli, P.; Meusburger, K.; Panagos, P. Using the USLE: Chances, challenges and limitations of soil erosion modelling. International Soil and Water Conservation Research, v. 7, n. 3, p. 203-225, 2019. https://doi.org/10.1016/j.iswcr.2019.05.004.

Alvares, C. A.; Stape, J. L.; Sentelhas, P. C.; Gonçalves, J. L. M.; Sparovek, G. Köppen's climate classification map for Brazil. Meteorologische Zeitschrift, v. 22, n. 6, p. 711-728, 2013. https:// doi.org/10.1127/0941-2948/2013/0507.

Baena, A. R. C.; Dutra, S. Propriedades físicas dos principais solos da Amazônia brasileira em condições naturais. Belém: Embrapa, 1982. 28p.

Bagarello, V.; Di Stefano, V.; Ferro, V.; Giordano, G.; lovino, M.; Pampalone, V. Estimating the USLE soil erodibility factor in Sicily, South Italy. Applied Engineering in Agriculture, v. 28, n. 2, p. 199206, 2012. https://doi.org/10.13031/2013.41347.

Batista, P. V. G.; Silva, M. L. N.; Silva, B. P. C.; Curi, N.; Bueni, I. T.; Acérbi Júnior, F. W.; Davies, J.; Quinton, J. Modelling spatially distributed soil losses and sediment yield in the upper Grande River Basin - Brazil. Catena, v. 157, n. 1, p. 139-150, 2017. https:// doi.org/10.1016/j.catena.2017.05.025.

Cerdà, A.; Rodrigo-Comino, J.; Giménez-Morera, A.; Novara, A.; Pulido, M.; Kapović-Solomun, M.; Keesstra, S. D. Policies can help to apply successful strategies to control soil and water losses. The case of chipped pruned branches (CPB) in Mediterranean citrus plantations. Land Use Policy, v. 75, n. 1, p. 734-745, 2018. https:// doi.org/10.1016/j.landusepol.2017.12.052. 
Dias, L. C. P.; Macedo, M. N.; Costa, M. H.; Coe, M. T.; Neil, C. Effects of land cover change on evapotranspiration and streamflow of small catchments in the Upper Xingu River Basin, Central Brazil. Journal of Hydrology: Regional Studies, v. 4, n. 1, p. 108-122, 2015. https://doi.org/10.1016/j.ejrh.2015.05.010.

Dias, L. C. P.; Pimenta, F. M.; Santos, A. B.; Costa, M. H.; Ladle, R. J. Patterns of land use, extensification, and intensification of Brazilian agriculture. Global Change Biology, v. 22, n. 1, p. 28872903, 2016. https://doi.org/10.1111/gcb.13314.

Dragičević, N.; Karleuša, B.; Ožanić, N. Erosion Potential Method (Gavrilović Method) Sensitivity Analysis. Soil \& Water Research, v. 12 , n. 1, p. 51-59, 2017. https://doi.org/10.17221/27/2016SWR.

Efthimiou, N.; Lykoudi, E.; Karavitis, C. Comparative analysis of sediment yield estimations using different empirical soil erosion models. Hydrological Sciences Journal, v. 62, n. 16, p. 2674-2694, 2017. https://doi.org/10.1080/02626667.2017.1404068.

Environmental Systems Research Institute - ESRI. ARCGIS Professional GIS for the desktop version 10.3. Redlands: ESRI, 2015. http:// desktop.arcgis.com/en/arcmap/10.3/get-started/quick-startguides/arcgis-desktopquick-start-guide.htm. 20 Nov. 2019.

Gavrilovic, S. A method for estimating the average annual quantity of sediments according to the potency of erosion. Bulletin of the Faculty of Forestry, v. 26, n. 1, p. 151-168, 1962.

Instituto Brasileiro de Geografia e Estatística - IBGE; Empresa Brasileira de Pesquisa Agropecuária - Embrapa. Mapa de solos do Brasil. Escala 1:5.000.000. Rio de Janeiro: IBGE, 2001.

Jung, S.; Polasky, S. Partnerships to prevent deforestation in the Amazon. Journal of Environmental Economics and Management, v. 92, n. 1, p. 498-516, 2018. https://doi.org/10.1016/j. jeem.2018.11.001.

Lal, R. Accelerated Soil erosion as a source of atmospheric $\mathrm{CO}_{2}$. Soil and Tillage Research, v. 188, n. 1, p. 35-40, 2019. https://doi. org/10.1016/j.still.2018.02.001.

Lense, G. H. E.; Parreiras, T. C.; Moreira, R. S.; Avanzi, J. C.; Mincato, R. L. Estimates of soil losses by the erosion potential method in tropical latosols. Ciência e Agrotecnologia, v. 43, e012719, 2019. https://doi.org/10.1590/1413-7054201943012719.

Luetzenburg, G.; Bittner, M.J.; Calsamiglia, A.; Renschler, S.; Estrany, J.; Poeppl, R. Climate and land use change effects on soil erosion in two small agricultural catchment systems Fugnitz Austria, Can Revull - Spain. Science of The Total Environment, v.704, n.1, e135389, 2020. https://doi.org/10.1016/j. scitotenv.2019.135389.

MapBiomas Project. Cobertura. 2018. (Coleção 4.1 do MapBiomas. Anuais de mapas de cobertura e uso de solo do Brasil, 1985 a 2018). http://plataforma.mapbiomas.org/map\#coverage. 24 Jan. 2020.

Martínez-Mena, M.; Carrillo-López, C.; Boix-Fayos, C.; Almagro, M.; Franco, N. G.; Díaz-Pereira, E.; Montoya, I.; Vente, J. Longterm effectiveness of sustainable land management practices to control runoff, soil erosion, and nutrient loss and the role of rainfall intensity in Mediterranean rainfed agroecosystems. Catena, v. 187, n. 1, e104352, 2020. https://doi.org/10.1016/j. catena.2019.104352.
Medeiros, G. O. R.; Giarolla, A.; Sampaio, G.; Marinho, M. A. Estimates of Annual Soil Loss Rates in the State of São Paulo, Brazil. Revista Brasileira de Ciência do Solo, v. 40, e0150497, 2016. https://doi. org/10.1590/18069657rbcs20150497.

Medeiros, L. C.; Medeiros, B. V. V.; Sobrinho, F. E.; Gurgel, M. T. Caracterização físico química de um neossolo litólico na região Seridó do RN. Agropecuária Científica no Semi-Árido, v. 9, n. 4, p. 01-07, 2013.

Oliveira, I. A.; Campos, M. C. C.; Freitas, L.; Soares, M. D. R. Caracterização de solos sob diferentes usos na região sul do Amazonas. Acta Amazonica, v. 45, n. 1, p. 1-12, 2015. https://doi. org/10.1590/1809-4392201400555.

Panagos, P.; Borrelli, P.; Poesen, J.; Ballabio, C.; Lugato, E.; Meusburger, K.; Montanarella, L.; Alewell, C. The new assessment of soil loss by water erosion in Europe. Environmental Science \& Policy, v. 54, n. 1, p. 438-447, 2015. https://doi.org/10.1016/j. envsci.2015.08.012.

Reydon, B.P.; Fernandes, V. B.; Telles, T. S. Land governance as a precondition for decreasing deforestation in the Brazilian Amazon. Land Use Policy, v. 94, n. 1, e104313, 2020. https://doi. org/10.1016/j.landusepol.2019.104313.

Sakuno, N. R. R.; Guiçardi, A. C. F.; Spalevic, V.; Avanzi, J. C.; Silva, M. L. N.; Mincato, R. L. Adaptation and application of the erosion potential method for tropical soils. Revista Ciência Agronômica, v. 51, n. 1, e20186545, 2020. https://doi.org/10.5935/1806-6690.20200004.

Sistema de indicação por radar de desmatamento na bacia do Xingu - SiradX. Boletim SiradX, n.16, p.1, 2019. https:// ox.socioambiental.org/sites/default/files/2020-02/boletim\%20 nov-dez\%2019_WEB_\%C6\%92.pdf. 22.Jun. 2020.

Sistema de indicação por radar de desmatamento na bacia do Xingu - SiradX. Boletim SiradX, n.17, p.1-7, 2020a. https:// ox.socioambiental.org/sites/default/files/2020-04/SiradX_ PG_13_Abr.pdf. 22. Jun. 2020.

Sistema de indicação por radar de desmatamento na bacia do Xingu - SiradX. Boletim SiradX, n.18, p.1-7, 2020b. https:// ox.socioambiental.org/sites/default/files/2020-06/SiradX_ MAR_ABR_PG_AF01_Tela.pdf. 22.Jun. 2020.

Stabile, M. C. C.; Guimarâes, A. L.; Silva, D. S.; Ribeiro, V.; Macedo, M. N.; Coe, M. T.; Pinto, E.; Moutinho, P.; Alencar, A. Solving Brazil's land use puzzle: Increasing production and slowing Amazon deforestation. Land Use Policy, v. 91, n. 1, e104362, 2020. https:// doi.org/10.1016/j.landusepol.2019.104362.

Tacconi, L.; Rodrigues, R. J.; Maryudi, A. Law enforcement and deforestation: Lessons for Indonesia from Brazil. Forest Policy and Economics, v. 108, n. 1, p. 1-10, 2019. https://doi.org/10.1016/j. forpol.2019.05.029.

Vanoni, V. A. Sediment deposition engineering. Washington: American Society of Civil Engineers, 1975. 745p. (Manuals and Reports on Engineering Practice, 54)

Villas-Bôas, A. De olho na Bacia do Xingu. São Paulo: Instituto Socioambiental, 2012. 63p.

Wadt, P. G. S. Estoque de carbono em um Plintossolo Argilúvico da Formação Solimões, Amazônia, Brasil. Rio Branco: Embrapa, 2004. 22p.

Wen, X.; Zhen, L. Soil erosion control practices in the Chinese Loess Plateau: a systematic review. Environmental Development, v. 34, n.1, e100493, 2020. https://doi.org/10.1016/j. envdev.2019.100493. 